\title{
ß-caryophyllene Oxide and Trans-nerolidol Affect Enzyme Activity of CYP3A4 - In Vitro and In Silico Studies
}

\author{
A. ŠPIČÁKOVÁ ${ }^{1}$, V. BAZGIER ${ }^{2}$, L. SKÁLOVÁ ${ }^{3}$, M. OTYEPKA ${ }^{2}$, P. ANZENBACHER $^{1}$ \\ ${ }^{1}$ Department of Pharmacology Faculty of Medicine, Palacký University, Olomouc, Czech Republic, \\ ${ }^{2}$ Regional Centre of Advanced Technologies and Materials, Department of Physical Chemistry, \\ Faculty of Science, Palacký University Olomouc, Czech Republic, ${ }^{3}$ Department of Biochemical \\ Sciences, Faculty of Pharmacy, Charles University, Hradec Králové, Czech Republic
}

Received June 21, 2019

Accepted July 4, 2019

\begin{abstract}
Summary
Evaluation of possible interactions with enzymes of drug metabolism is an important part of studies on safety and, in general, on the properties of any drug or biologically active compound. Here, focus is given on interactions of three sesquiterpenes ( $\beta$-caryophyllene oxide (CAO), trans-nerolidol (tNER) and farnesol (FAR)) with CYP3A4. To determine the CYP3A4 activity, specific substrates testosterone (TES) and midazolam (MDZ) were used. In human liver microsomes, the CAO inhibited the MDZ 1 '-hydroxylation by mixed type inhibition and $\mathrm{K}_{\mathrm{i}} 46.6 \mu \mathrm{M}$; TES $6 \beta$-hydroxylation was inhibited more strongly by tNER by the same mechanism and with $K_{i}$ of $32.5 \mu \mathrm{M}$. Results indicated a possibility of different mode of interaction of both compounds within the active site of CYP3A4 and this was why the molecular docking study was done. The docking experiments showed that the studied sesquiterpenes (CAO and tNER) bound to the CYP3A4 active site cause a significant decrease of binding affinity of substrates tested which corresponded well to the inhibition studies. The inhibition observed, however, most probably does not pose a real harm to microsomal drug metabolism as the levels of sesquiterpenes in plasma (assuming the use of these compounds as spices or flavoring additives) does not usually exceed micromolar range. Hence, the interaction of drugs metabolized by CYP3A4 with sesquiterpenes is less probable.
\end{abstract}

\section{Key words}

$\beta$-caryophyllene oxide $\bullet$ Trans-nerolidol $\bullet$ CYP3A4 $\bullet$ In vitro $\bullet$ In silico

\section{Corresponding author}

A. Špičáková, Department of Pharmacology, Faculty of Medicine, Palacký University, Hněvotínská 3, 77515 Olomouc, Czech Republic. E-mail: alena.spicakova@upol.cz

\section{Introduction}

Cytochromes P450 (CYP) are the most important enzymes of the drug metabolism (Anzenbacher and Anzenbacherová 2001, Anzenbacher and Zanger 2012, Ortiz de Montellano 2005, Zanger and Schwab 2013). These hemoproteins are localized in many tissues of the human organism (e.g. liver, lungs, brain, heart, kidney, and intestines). Subcellular localization of CYP enzymes is typically in the membrane of endoplasmatic reticulum and mitochondria (Šrejber et al. 2018). The main function of CYPs is formation of more polar metabolites of drugs either by inserting of polar group into parent molecule (e.g. hydroxylation) or by liberation of a present functional group (e.g. demethylation of a methoxy group). Fifty-seven human CYP forms are known; in pharmacology focus is given to CYP present in human liver and important in biotransformation of drugs (Anzenbacher and Anzenbacherová 2001, Anzenbacher and Zanger 2012, Guengerich 2003).

An evaluation of possible interactions with enzymes of drug metabolism is necessary part of studies on safety and, in general, on the properties of any drug or biologically active compound. Drug interactions often involve interactions with compounds of natural origin (Anadón et al. 2016, Hermann and von Richter 2012), as it has been documented e.g. for drug substrates of cytochrome P450 form CYP3A4 with compounds present in Hypericum perforatum (St. John's Wort) extracts (Hall et al. 2003, Greeson et al. 2001, Wang et al. 2001) or in grapefruit juice (Anadón et al. 2016, Bailey et al. 1998, Chan 2006). Drug interactions of this kind may lead to 
serious consequences, as e.g. to a rejection of heart transplant due to lowered cyclosporine A levels (cyclosporine A is a typical CYP3A4 substrate) after intake of Hypericum perforatum extract (Ruschitzka et al. 2000).

Sesquiterpenes are group of terpenes consisting of three isoprene units and fifteen carbons. They occur in human food, beverages, and they are inherent ingredients of spices. Moreover, they are the main component of plant essential oils widely used in folk medicines, cosmetics or pharmaceutical industry (Bártíková et al. 2014, Marcin and Nad' 2017). Bicyclic sesquiterpene $\beta$-caryophyllene (CAR) mainly occurs in nature together with its monocyclic isomer $\alpha$-humulene, as well as with its metabolite, a monooxygenated derivative $\beta$-caryophyllene oxide (CAO; Fig. 1). These cyclic sesquiterpenes are components of well-known aromatic plants such as basil, oregano, sage, menthe, ginger, cloves, lemon balm, caraway, hops, lavender, rosemary, cinnamon, cannabis etc. Cyclic sesquiterpenes are known to have favorable biological activities, e.g. anticancer and analgesic activity (Fidyt et al. 2017), antioxidant, antimicrobial, chemo-protective, anti-inflammatory effect, and cytotoxicity in cancer cells. The acyclic sesquiterpenes (Fig. 1), also known as farnesans, are derived from farnesol (FAR). Farnesol occurs in many plants, e.g. cabreuva, ambrette, jasmine, ylang and rose. The isomer of FAR, nerolidol (NER), exists in two geometric isomers - a trans and a cis isoform. NER is a frequent component in food and cosmetics. Acyclic sesquiterpenes exhibit similar biological activities reviewed in Chan et al. (2016) (e.g. antioxidant, antibacterial, antiparasitic and anticancer). Recently, it has been also shown that CAO enhances the efficacy of 5-fluorouracil and oxaliplatin in colon cancer cells (Ambrož et al. 2019).

Interactions of sesquiterpenes with CYP were investigated recently (Špičáková et al. 2017, Nguyen et al. 2017); here, focus is given to their interaction and possible inhibition of the most important enzyme of drug metabolism in humans, namely, with CYP3A4 (Anzenbacher and Zanger 2012, Ortiz de Montellano 2005).

To get a structural insight into mechanism of inhibition of CYP3A4 by sesquiterpenes we performed also the molecular docking of $\mathrm{CAO}$, trans-nerolidol (tNER) and FAR in CYP3A4 enzyme. Molecular modeling can help in understanding the relationship between structure and function of proteins involved in many biological processes. This approach has been shown to be useful in explaining stereoselective interactions of many compounds with CYP enzymes (Berka et al. 2012, Krasulová et al. 2015, Krasulová et al. 2017, Otyepka et al. 2012).<smiles>C=CC(C)(O)CC/C=C(\C)CCC=C(C)C</smiles><smiles>CCCCC(C)=CCCC(C)=CCO</smiles>

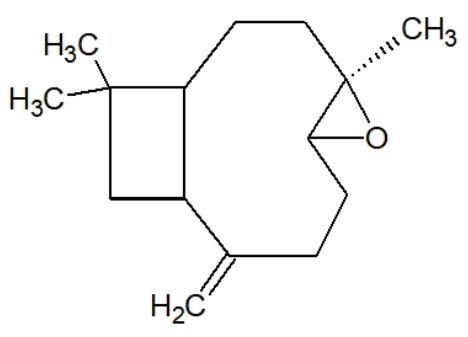

$\beta$-caryophyllene oxide

Fig. 1. Structural formulae of used sesquiterpenes. Chemical structures were produced using $\mathrm{ACD} /$ ChemSketch (Freeware) 2017.2.1.

\section{Methods}

\section{Chemicals and reagents}

The cyclic (CAO) and acyclic sesquiterpenes (tNER and FAR) were obtained from the laboratory of the co-author (LS) (Špičáková et al. 2017, Nguyen et al. 2017).

Midazolam (MDZ), testosterone (TES), NADP ${ }^{+}$, isocitric acid and isocitratedehydrogenase were purchased from Sigma (Sigma Aldrich CZ, Prague). All other common laboratory chemicals were obtained from the same source and of the HPLC or analytical grade. Microsomal fraction of human liver homogenate was purchased from Biopredic (Rennes, France).

\section{Enzyme assays}

To study the CYP3A4 enzyme activity we have used two established methods described to the literature with CYP3A4 specific substrates TES (Guengerich et al. 
1986) and MDZ (Gorski et al. 1994), namely, the 1 '-hydroxylation of MDZ and TES 6 $\beta$-hydroxylation.

Incubation mixtures contained $100 \mathrm{mM}$ potassium phosphate buffer ( $\mathrm{pH} 7.4$ ), NADPH-generating system $\left(0.8 \mathrm{mM} \mathrm{NADP}^{+}, 5.8 \mathrm{mM}\right.$ isocitric acid, $0.3 \mathrm{unit} / \mathrm{ml}$ of isocitrate dehydrogenase and $8 \mathrm{mM} \mathrm{MgCl}_{2}$ ), human liver microsomes and individual probe substrate. Assay conditions are listed in Table 1. For determination of metabolites formed from specific substrates, an HPLC system Shimadzu Class VP HPLC system (Shimadzu, Tokyo, Japan) with UV detection (for 1'-hydroxymidazolam $240 \mathrm{~nm} ; 245 \mathrm{~nm}$ for $6 \beta$-hydroxytestosterone) was used. Inhibition of individual CYP activities was in all cases evaluated by plotting respective remaining activity against the inhibitor concentration.

\section{Enzyme inhibition studies}

Initially, for both enzyme assays, preliminary experiment was done to determine the $\mathrm{K}_{\mathrm{M}}$ and $\mathrm{V}_{\max }$ to obtain the appropriate concentration of the specific substrates for the inhibition experiments. Substrate concentration was chosen in the range corresponding to the value of $\mathrm{K}_{\mathrm{M}}$. Data were analyzed using the SigmaPlot 8.0 graphing software (Jandel Scientific, Chicago, IL, USA).

Inhibition experiments were performed as duplicate experiments at $0,5,10,25,50$, and $100 \mu \mathrm{M}$ concentration of each tested sesquiterpenes with individual values differing less than $10 \%$. Preincubation of reaction mixtures with potential inhibitors (CAO, tNER and FAR) for $30 \mathrm{~min}$ at $37^{\circ} \mathrm{C}$ was performed in both assays. The same experiment with organic solvent was performed too. Inhibition of CYP3A4 activity was in both cases evaluated by plotting respective remaining activity against the inhibitor concentration.

\section{Statistical analysis}

Calculations of microsomal CYP activities were done using Microsoft Excel 2016 and Statistica 12 (Systat Software, San Jose, CA). Data were analyzed by one-way analysis of variance and then Scheffé's post hoc test. The differences were regarded as significant when $* \mathrm{p}<0.05$, $\# \mathrm{p}<0.01, \dagger \mathrm{p}<0.001, \$ \mathrm{p}<0.0001$.

\section{Molecular modelling}

Ligand structures of MDZ, TES, CAO, tNER and FAR were prepared for docking procedure using MarvinSketch 15.1.5.0 software package (http://www.chemaxon.com). Polar hydrogens were added and Kollman charges assigned using Autodock
Tools program package (Sanner 1999). Autodock Vina program (Trott and Olson 2010) was used for docking of ligands into the grid box containing whole structure of CYP3A4 protein model centered on enzyme center near to the heme cofactor. The crystal structure of CYP3A4 enzyme (PDBID: 5A1R) was used to construct the enzyme/protein docking templates. The affinity to the enzyme was estimated using Gibbs free energy $(\Delta G)$ of $\mathrm{E}+\mathrm{L}=\mathrm{EL}$ reaction, where $\mathrm{L}$ stands for ligand (substrate or inhibitor), E for enzyme and EL for enzyme-ligand complex. It should be noted that $\Delta G=-\mathrm{R} T \ln K$, where $\mathrm{R}$ is the universal gas constant, $T$ thermodynamic temperature and $\mathrm{K}$ the equilibrium constant of the interaction.

\section{Results}

Inhibition of specific CYP activities in human liver microsomes

In the present study, inhibitory effect of four sesquiterpenes (CAO, tNER and FAR) on enzyme activity of CYP3A4 was investigated. For measurement of the changes in the activity of CYP3A4, of two different substrates (MDT and TES) were studied. Firstly, MDZ with its specific metabolite 1'-hydroxymidazolam, and secondly, TES with its specific metabolite $6 \beta$-hydroxytestosterone were used. tNER and CAO inhibited enzyme activity of CYP3A4 (Figs 2A and 2B). $\mathrm{IC}_{50}$ value of inhibition of midazolam 1'-hydroxylation by CAO amounted to $26.3 \mu \mathrm{M}$ (Fig. $2 \mathrm{~A}$ ) and to $46.3 \mu \mathrm{M}$ for the inhibition of $6 \beta$-hydroxytestosterone formation by tNER (Fig. 2B). Insignificant inhibition was observed in other cases.

Further experiments were performed to determine the mechanism of inhibition of MDZ and TES metabolite formation by $\mathrm{CAO}$ and tNER. Enzyme kinetics of CYP3A4 using both probes, MDZ and TES, were determined to find the optimal concentration of the specific substrates for the inhibition experiments. Substrate concentrations were chosen close to $K_{M}$ values (Table 1). Then, experiments assessing inhibition of activity of this enzyme (using both probes MDZ and TES), by CAO, tNER and FAR were performed. The measurements were made at four substrate concentrations corresponding to $0.5 \mathrm{~K}_{\mathrm{M}}, 1 \mathrm{~K}_{\mathrm{M}}, 2 \mathrm{~K}_{\mathrm{M}}$, and $4 \mathrm{~K}_{\mathrm{M}}$ values $(1.25,2.5,5$, and $10 \mu \mathrm{M}$ for MDZ; and 50, 100, 200, and $400 \mu \mathrm{M}$ for TES) for analysis of the inhibition mechanism by Dixon and Lineweaver-Burk plots (Segel 1993). 
Table 1. Incubation conditions for CYP3A4 assays used in the inhibition study.

\begin{tabular}{lcccc}
\hline Substrate & $\begin{array}{c}\text { Substrate conc. } \\
(\boldsymbol{\mu M})\end{array}$ & $\begin{array}{c}\mathbf{C Y P} / \mathbf{v o l u m e} \\
(\mathbf{p m o l} / \boldsymbol{\mu l})\end{array}$ & Quench agent & $\begin{array}{c}\text { Incubation time } \\
(\mathbf{m i n})\end{array}$ \\
\hline Midazolam & 2.5 & $15 / 100$ & $0.1 \mathrm{ml}$ methanol & 10 \\
Testosterone & 100 & $70 / 500$ & $2.0 \mathrm{ml}$ dichlormethane & 30 \\
\hline
\end{tabular}

Table 2. Binding free energy to the CYP3A4 active site $(\Delta G, \mathrm{kcal} / \mathrm{mol})$ of sesquiterpenes and CYP3A4 substrates. A, the compounds alone; $\mathbf{B}$, changes of $\Delta G$ of substrates in presence of sesquiterpenes in the CYP3A4 active site.

\begin{tabular}{lccccc}
\hline $\mathbf{A}$ & \multicolumn{1}{c}{} & & & \\
\hline Compound & CAO & tNER & FAR & MDZ & TES \\
$\Delta G$ & -7.6 & -6.6 & -6.8 & -9.8 & -6.6 \\
\hline B & & & & TES+tNER & TES+FAR \\
\hline Compound & MDZ & MDZ+CAO & TES & -3.6 & -5.1 \\
\hline$G$ & -9.8 & -4.5 & -6.6 & & \\
\hline
\end{tabular}

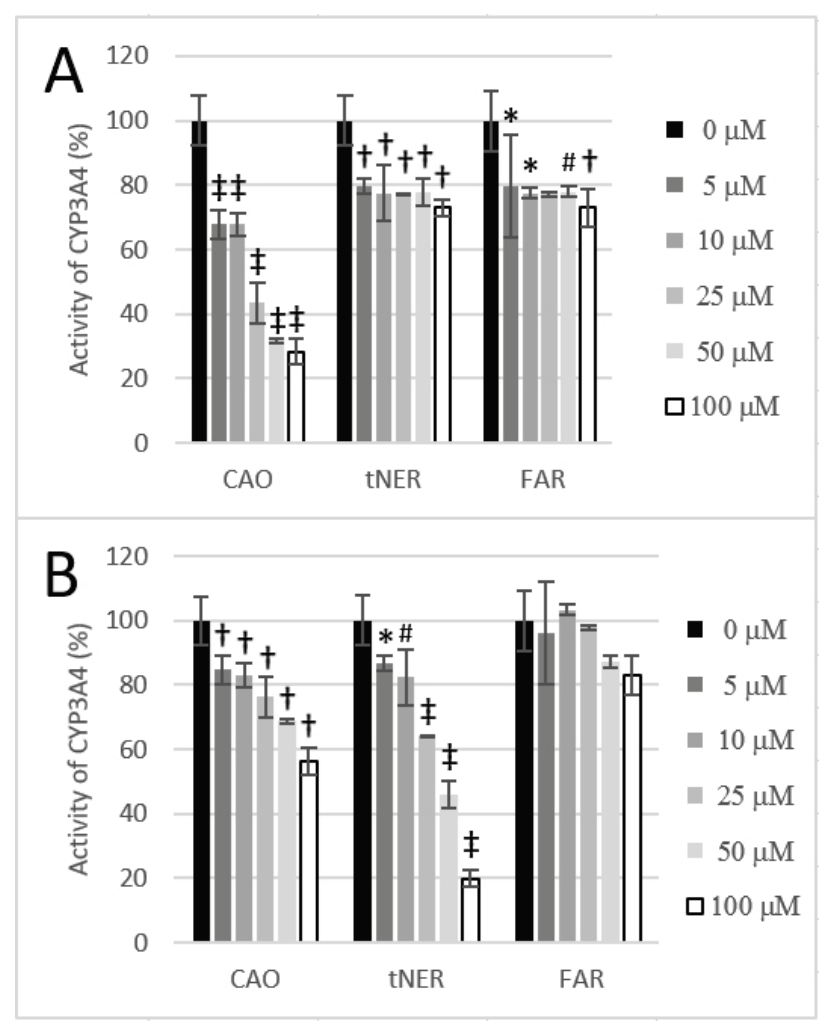

Fig. 2. Effects of sesquiterpenes (CAO, tNER and FAR) on enzyme activity of CYP3A4, substrate midazolam (A) and substrate testosterone (B), in human liver microsomes. Inhibition of enzyme activity is expressed as the activity remaining relative to control (100\%, without sesquiterpene) in percent. Concentration of an individual sesquiterpenes in the reaction mixture was $0,5,10,25,50$, and $100 \mu \mathrm{M}$. Data were analyzed by one-way ANOVA and then Scheffé's post hoc test. Activities represent the mean from three independent experiments in duplicates and values significantly different from control are labeled $(N=6, * p<0.05, \# p<0.01,+p<0.001, \neq p<0.0001)$.
A

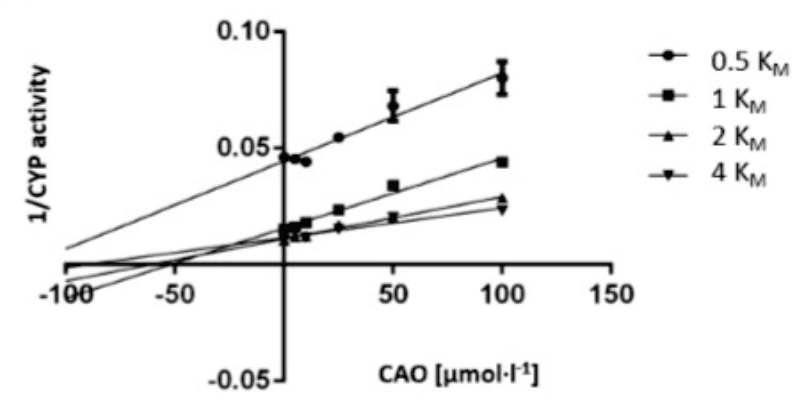

B

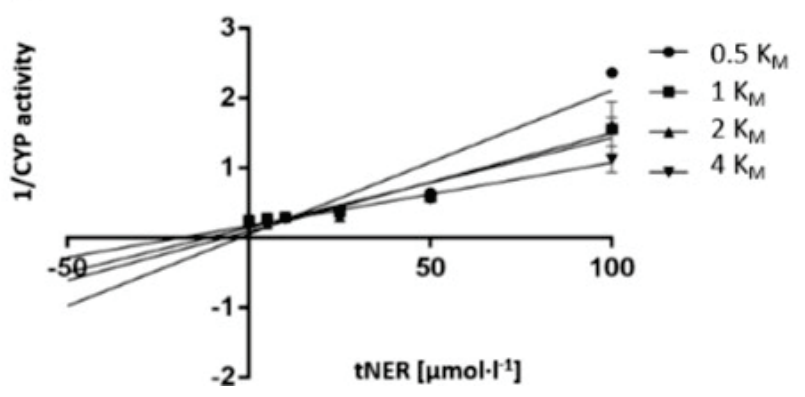

Fig. 3. Dixon plots (A) representing inhibition of 1 '-hydroxylation of midazolam by CAO after a 30 -min preincubation; (B) illustrating the inhibition of $6 \beta$-hydroxylation of testosterone by tNER after a 30 -min preincubation (for details, see Methods).

The most prominent inhibitory effects, i.e. more than down to $50 \%$ of initial activity (Fig. 2A inhibition of MDZ 1'-hydroxylation by CAO, or Fig. 2B inhibition of TES $6 \beta$-hydroxylation by tNER), were evaluated by creating the Dixon as well as the Lineweaver-Burk 
plots (data not shown) of the enzyme activity as a function of inhibitor concentration. The formation of 1 '-hydroxymidazolam is inhibited by CAO by mixed type inhibition (Fig. 3A), similarly, tNER inhibits $6 \beta$-hydroxylation of TES by the same mixed inhibition mechanism (Fig. 3B). The respective $\mathrm{K}_{\mathrm{i}}$ values obtained were found to be $46.6 \mu \mathrm{M}$ (for $\mathrm{CAO}$ with $\mathrm{MDZ}$ ), and $32.5 \mu \mathrm{M}$ (for tNER with TES).

\section{Molecular modelling}

Molecular docking was used for analysis of interactions of three sesquiterpenes (FAR, CAO and tNER) and two substrates (MDZ and TES) within the active site of CYP3A4 in terms of Gibbs free energies. We carried out docking experiments for each molecule into crystal structure of CYP3A4 and averaged the estimated free energies. The Gibbs free energy reflects affinity of ligand molecule to the active site and is related to the equilibrium constant (see Methods). Lower value of the Gibbs free energy corresponds to higher ligand affinity (tougher binding). The studied sesquiterpenes exhibited rather similar binding energies ranging from -6.6 to $-7.6 \mathrm{kcal} / \mathrm{mol}$ (Table 2). The molecules bind above the heme cofactor (Fig. 4A) interacting besides the heme mostly with I-helix amino acids at the left to the heme. As the prototypical substrates (MDZ and TES) bind to similar position as sesquiterpenes, they can block access of substrates to the heme and inhibit the enzyme. This idea is corroborated by the interaction energies of MDZ and TES (-9.8 and $-6.6 \mathrm{kcal} / \mathrm{mol}$ ), which are not far from the binding energies of sesquiterpenes. The competing binding positions of substrates and sesquiterpenes apparently contributed to the experimentally observed inhibition. However, it is worth noting that under physiological conditions, one should take into account that the CYP3A4 catalytical activity will be affected by current local concentrations of interacting compounds as well as by molecular dynamics (Berka et al. 2013, Paloncýová et al. 2014, Šrejber et al. 2018).

Next, we carried out a docking study showing the binding of substrates in presence of bound sesquiterpenes. The sesquiterpenes which were able to inhibit the CYP3A4 enzyme activity were: CAO (inhibiting preferably the MDZ 1'-hydroxylation; Fig. 2A) and tNER (inhibiting the TES 6 $\beta$-hydroxylation; Fig. 2B). In the Figure 4B, the binding of $\mathrm{MDZ}$ in presence of $\mathrm{CAO}$ is shown documenting the displacement of MDZ from the center of the active site as the CAO occupied the space above the heme. This also explains the inhibition of MDZ $1^{\prime}$-hydroxylation and is supported by change of $\Delta G$ of
MDZ from $-9.8 \mathrm{kcal} / \mathrm{mol}$ to $-4.5 \mathrm{kcal} / \mathrm{mol}$ indicating a decrease of binding affinity of the MDZ (Table 2). Similarly, the binding of TES in presence of inhibiting molecule, here the tNER (results not shown), the displacement of TES from the original binding site has led to inhibition of the TES $6 \beta$-hydroxylation and change of $\Delta G$ of TES from $-6.6 \mathrm{kcal} / \mathrm{mol}$ to $-3.6 \mathrm{kcal} / \mathrm{mol}$, again showing a decreased affinity of TES to the enzyme (Table 2).

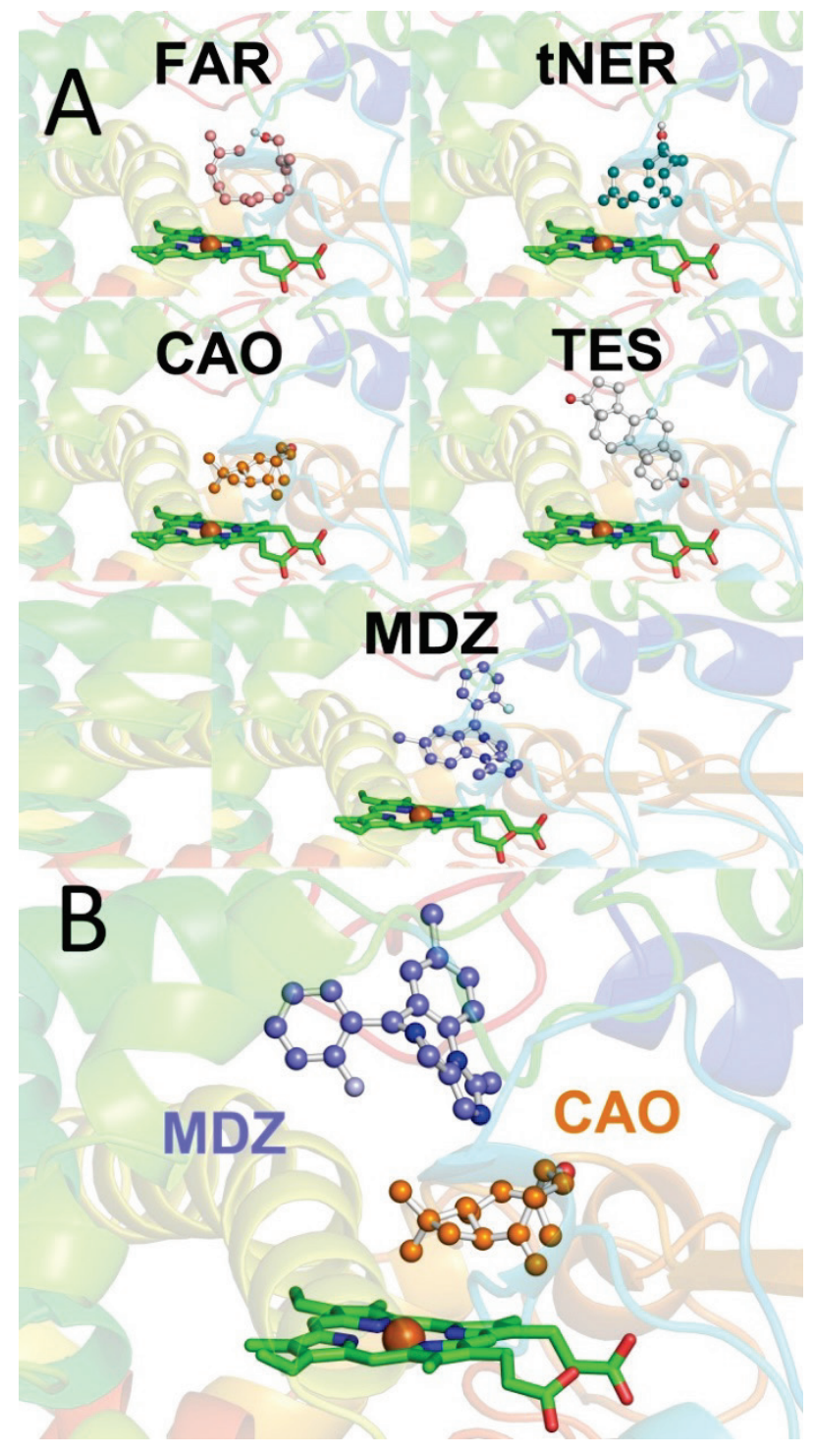

Fig. 4. Preferred orientation of studied molecules inside the active site of CYP3A4 (PDB ID: 5A1R) as predicted by the docking experiment. CYP3A4 is represented by secondary structure elements, heme is highlighted in sticks, and ligands by ball\&stick models. A, sesquiterpenes and substrates TES and MDZ alone; B, MDZ and CAO together showing the displacement of MDZ from the heme vicinity.

An example of sesquiterpene, which is not inhibiting the CYP3A4 activities, is represented by FAR. 
This molecule does inhibit neither the MDZ 1 '-hydroxylation, nor the TES $6 \beta$-hydroxylation by this enzyme. Apparently, this is caused by displacement of FAR from the heme vicinity (not shown). This may be demonstrated with TES, with only relatively small change of the binding energy (TES alone, -6.6 kcal/mol; TES+FAR, $-5.1 \mathrm{kcal} / \mathrm{mol}$; Table 2) indicating relatively small influence of this compound on the CYP3A4 enzyme activity (Fig. 2).

\section{Discussion}

The sesquiterpenes, including the three compounds studied here (CAO, tNER and FAR) often occur in plants together. They are common components of food, beverages, cosmetics and preparations of folk medicine. Furthermore, these natural compounds possess promising biological activities (Bártíková et al. 2014). On the other hand, as with other biologically active compounds, including those of the natural origin, there is a risk of unfavorable drugs interactions (for examples see Introduction). CYP3A4 is the most important enzyme of drug metabolism in humans (Anzenbacher and Anzenbacherová 2001, Anzenbacher and Zanger 2012); hence, sesquiterpene-drug interactions based on CYP3A4 could lead to clinical consequences. Recently, interactions of sesquiterpenes with hepatic cytochromes P450 has been studied (Koe at el. 2013, Pimkaew et al. 2013).

In the present study, an inhibitory effect of three sesquiterpenes (CAO, tNER and FAR) on the activity of the CYP3A4 enzyme in human liver microsomal fraction was studied in detail.

Summarized results of the inhibition experiments are shown in Figure 2. Among three sesquiterpenes studied, tNER and CAO were shown to able to affect the enzyme activity of CYP3A4. Interestingly, the results show that both the prototypical activities of CYP3A4 are inhibited by tNER and CAO, reflecting the similarity of mode of interaction in the CYP3A4 active site. CAO inhibits the prototypical
CYP3A4 enzyme activity (MDZ 1'-hydroxylation) by binding strongly to the active site which is typical for binding of the substrate MDZ, in other words, CAO occupies the optimal binding site of MDZ. This situation is also documented by decrease of the binding energy of MDZ from $-9.8 \mathrm{kcal} / \mathrm{mol}$ to $-4.5 \mathrm{kcal} / \mathrm{mol}$ in the presence of CAO (Table 2). This is clearly seen in the Figure 4. Analysis of the inhibition mechanism indicates a mixed type inhibition, in other words, a mechanism which mixes a competitive inhibition which is, however, influenced by catalytic properties of the enzyme (Segel 1993, CornishBowden 2004). tNER interacts within the CYP3A4 active site in a similar location. This is why the binding energy of TES in presence of inhibitor tNER is again lowered almost by one half (from $6.6 \mathrm{kcal} / \mathrm{mol}$ to $3.6 \mathrm{kcal} / \mathrm{mol}$, Table 2). As in the case of CAO, the mechanism of inhibition indicates again a mixed type of inhibition (a competitive inhibition interfering catalytic properties of the enzyme (Segel 1993, Cornish-Bowden 2004)). Inhibition in both cases can be expressed by the respective $\mathrm{K}_{\mathrm{i}}$ values of $46.6 \mu \mathrm{M}$ for inhibition of 1 '-hydroxylation of MDZ by $\mathrm{CAO}$; and $32.5 \mu \mathrm{M}$ for inhibition of TES $6 \beta$-hydroxylation by tNER.

In other words, due to relatively high values of the $\mathrm{K}_{\mathrm{i}}$ 's, the inhibition observed most probably does not pose real harm to microsomal drug metabolism as the levels of sesquiterpenes in plasma (assuming the use of these compounds as spices or flavoring additives) do not usually exceed micromolar range (Yang et al. 2012, de Araújo Delmondes et al. 2019). Hence, the interaction of drugs metabolized by CYP3A4 is less probable and the compounds can be expected to be safe.

\section{Conflict of Interest}

There is no conflict of interest.

\section{Acknowledgements}

This work was supported by internal student grant of UPOL (IGA_LF_2019_011), Czech MEYS Project (CZ.02.2.69/0.0/0.0/16) and NPU project (LO1304).

\section{References}

ANADÓN A, MARTÍNEZ-LARRAÑAGA MR, ARES I, MARTÍNEZ MA: Interactions between Nutraceutilas/ Nutrients and Therapeutic Drugs. In: Nutraceuticals, Efficacy, Safety and Toxicity. RC GUPTA (ed.), Academic Press, Massachusetts, USA, 2016, pp 855-874.

ANZENBACHER P, ANZENBACHEROVÁ E: Cytochromes P450 and metabolism of xenobiotics. Cell Mol Life Sci 58: $737-747,2001$. 
ANZENBACHER P, ZANGER UM: Metabolism of Drugs and Other Xenobiotics. Wiley-VCH Verlag \& Co KGaA, Germany, 2012.

AMBROŽ M, ŠMATOVÁ M, ŠADIBOLOVÁ M, POSPÍŠILOVÁ E, HADRAVSKÁ P, KAŠPAROVÁ M, HANUŠOVÁ SKARKOVÁ V, KRÁLOVÁ V, SKÁlOVÁ L: Sesquiterpenes $\alpha$-humulene and $\beta$-caryophyllene oxide enhance the efficacy of 5-fluorouracil and oxaliplatin in colon cancer cells. Acta Pharm 69: 121-128, 2019.

BAILEY DG, MALCOLM J, ARNOLD O, SPENCE JD: Grapefruit juice-drug interactions. 1998. Br J Clin Pharmacol 58: S831-S840; discussion S841-S843, 2004.

BÁRTÍKOVÁ H, HANUŠOVÁ V, SKÁLOVÁ L, AMBROŽ M, BOUŠOVÁ I: Antioxidant, pro-oxidant and other biological activities of sesquiterpenes. Curr Top Med Chem 14: 2478-2494, 2014.

BERKA K, ANZENBACHEROVÁ E, HENDRYCHOVÁ T, LANGE R, MAŠEK V, ANZENBACHER P, OTYEPKA $\mathrm{M}$ : Binding of quinidine radically increases the stability and decreases the flexibility of the cytochrome P450 2D6 active site. J Inorg Biochem 110: 46-50, 2012.

BERKA K, PALONCÝOVÁ M, ANZENBACHER P, OTYEPKA M: Behavior of human cytochromes P450 on lipid membranes. J Phys Chem B 117: 11556-11564, 2013.

CHAN LN: Drug-nutrient interactions. In: Modern Nutrition in Health and Disease. ME SHILS, M SHIKE, AC ROSS, B CABALlERO, RJ COUSINS (eds), Lippincott Williams \& Wilkins, Baltimore, Maryland, 2006, pp 1540-1553.

CHAN WK, TAN LT, CHAN KG, LEE LH, GOH BH: Nerolidol: a sesquiterpene alcohol with multi-faceted pharmacological and biological activities. Molecules 21: E529, 2016.

CORNISH-BOWDEN A: Fundamentals of Enzyme Kinetics. Third edition. Portland Press, London, 2004, p. 114-120.

De ARAÚJO DELMONDES G, BEZERRA DS, DE QUEIROZ DIAS D, DE SOUZA BORGES A, ARAÚJO IM, LINS DA CUNHA G, BANDEIRA PFR, BARBOSA R, MELO COUTINHO HD, FELIPE CFB, BARBOSAFILHO JM, ALENCAR DE MENEZES IR, KERNTOPF MR: Toxicological and pharmacologic effects of farnesol (C15H26O): a descriptive systematic review. Food Chem Toxicol 129: 169-200, 2019.

FIDYT K, FIEDOROWICZ A, STRZĄDAŁA L, SZUMNY A: $\beta$-caryophyllene and $\beta$-caryophyllene oxide-natural compounds of anticancer and analgesic properties. Cancer Med 5: 3007-3017, 2016.

GORSKI JC, HALL SD, JONES DR, VANDENBRANDEN M, WRIGHTON SA: Regioselective biotransformation of midazolam by members of the human cytochrome P450 3A (CYP3A) subfamily. Biochem Pharmacol 47: 1643-1653, 1994.

GREESON JM, SANFORD B, MONTI DA: St. John's wort (Hypericum perforatum): a review of the current pharmacological, toxicological, and clinical literature. Psychopharmacology (Berl) 153: 402-414, 2001.

GUENGERICH FP: Cytochromes P450, drugs, and diseases. Mol Interv 3: 194-204, 2003.

GUENGERICH FP, MARTIN MV, BEAUNE PH, KREMERS P, WOLFF T, WAXMAN DJ: Characterization of rat and human liver microsomal cytochrome P-450 forms involved in nifedipine oxidation, a prototype for genetic polymorphism in oxidative drug metabolism. J Biol Chem 261: 5051-5060, 1986.

HALL SD, WANG Z, HUANG SM, HAMMAN MA, VASAVADA N, ADIGUN AQ, HILLIGOSS JK, MILLER M, GORSKI JC: The interaction between St John's wort and an oral contraceptive. Clin Pharmacol Ther 74: 525-535, 2003.

HERMANN R, VON RICHTER O: Clinical evidence of herbal drugs as perpetrators of pharmacokinetic drug interactions. Planta Med 78: 1458-1477, 2012.

KOE XF, LIM EL, SEAH TC, AMANAH A, WAHAB HA, ADENAN MI, SULAIMAN SF, TAN ML: Evaluation of in vitro cytochrome $\mathrm{P} 450$ induction and inhibition activity of deoxyelephantopin, a sesquiterpene lactone from Elephantopus scaber L. Food Chem Toxicol 60: 98-108, 2013.

KRASULOVÁ K, HOLAS O, ANZENBACHER P: Influence of amlodipine enantiomers on human microsomal cytochromes P450: stereoselective time-dependent inhibition of CYP3A enzyme activity. Molecules 22: E1879, 2017.

KRASULOVÁ K, ŠILLER M, HOLAS O, DVOŘÁK Z, ANZENBACHER P: Enantiospecific effects of chiral drugs on cytochrome P450 inhibition in vitro. Xenobiotica 46: 315-324, 2016. 
MARCIN A, NAD P: Effect of essential oils on enzymatic activities in the intestinal apparatus and growth ability of laboratory mice. Physiol Res 66 (Suppl 4): S567-S574, 2017.

NGUYEN LT, MYSLIVEČKOVÁ Z, SZOTÁKOVÁ B, ŠPIČÁKOVÁ A, LNĚNIČKOVÁ K, AMBROŽ M, KUBÍČEK V, KRASULOVÁ K, ANZENBACHER P, SKÁLOVÁ L: The inhibitory effects of $\beta$-caryophyllene, $\beta$-caryophyllene oxide and $\alpha$-humulene on the activities of the main drug-metabolizing enzymes in rat and human liver in vitro. Chem Biol Interact 278: 123-128, 2017.

ORTIZ DE MONTELLANO PR: Cytochrome P450: Structure, Mechanism, and Biochemistry. 3rd edition. Kluwer Academic/Plenum, New York, 2005.

OTYEPKA M, BERKA K, ANZENBACHER P: Is there a relationship between the substrate preferences and structural flexibility of cytochromes P450? Curr Drug Metab 13: 130-142, 2012.

PALONCÝOVÁ M, DEVANE R, MURCH B, BERKA K, OTYEPKA M: Amphiphilic drug-like molecules accumulate in a membrane below the head group region. J Phys Chem B 118: 1030-1039, 2014.

PIMKAEW P, KÜBLBECK J, PETSALO A, JUKKA J, SUKSAMRARN A, JUVONEN R, AURIOLA S, PIYACHATURAWAT P, HONKAKOSKI P: Interactions of sesquiterpenes zederone and germacrone with the human cytochrome P450 system. Toxicol In Vitro 27: 2005-2012, 2013.

RUSCHITZKA F, MEIER PJ, TURINA M, LÜSCHER TF, NOLL G: Acute heart transplant rejection due to Saint John's wort. Lancet 355: 548-549, 2000.

SANNER MF: Python: a programming language for software integration and development. J Mol Graph 17: 57-61, 1999.

SEGEL IH: Enzyme Kinetics. Behavior and Analysis of Rapid Equilibrium and Steady-State Enzyme Systems. WileyInterscience, New York, 1993, pp 100-224.

ŠPIČÁKOVÁ A, SZOTÁKOVÁ B, DIMUNOVÁ D, MYSLIVEČKOVÁ Z, KUBÍČEK V, AMBROŽ M, LNĚNIČKOVÁ K, KRASULOVÁ K, ANZENBACHER P, SKÁLOVÁ L: Nerolidol and farnesol inhibit some cytochrome $\mathrm{P} 450$ activities but did not affect other xenobiotic-metabolizing enzymes in rat and human hepatic subcellular fractions. Molecules 22: 509, 2017.

ŠREJBER M, NAVRÁTILOVÁ V, PALONCÝOVÁ M, BAZGIER V, BERKA K, ANZENBACHER P, OTYEPKA M: Membrane-attached mammalian cytochromes P450: an overview of the membrane's effects on structure, drug binding, and interactions with redox partners. J Inorg Biochem 183: 117-136, 2018.

TROTT O, OLSON AJ: Software news and update Autodock Vina: improving the speed and accuracy of docking with a new scoring function, efficient optimization, and multithreading. J Comput Chem 31: 455-461, 2010.

WANG Z, GORSKI JC, HAMMAN MA, HUANG SM, LESKO LJ, HALL SD: The effects of St John's wort (Hypericum perforatum) on human cytochrome P450 activity. Clin Pharmacol Ther 70: 317-326, 2001.

YANG X, SU J, HE Y, LIU H, LI H, ZHANG W: Simultaneous determination of three sesquiterpene lactones from Herba Inula extract in rat plasma by LC/MS/MS and its application to pharmacokinetic study. J Chromatogr B Analyt Technol Biomed Life Sci 903: 40-45, 2012.

ZANGER UM, SCHWAB M: Cytochrome P450 enzymes in drug metabolism: regulation of gene expression, enzyme activities, and impact of genetic variation. Pharmacol Ther 138: 103-141, 2013. 